\title{
MODEL PEMBERDAYAAN PEREMPUAN MISKIN MELALUI PELATIHAN KEWIRAUSAHAAN BERBASIS POTENSI LOKAL DI KECAMATAN WEDI KABUPATEN KLATEN
}

\author{
Agung Utama, Titin Hera Widi Handayani \\ Universitas Negeri Yogyakarta \\ email: titinhera_widi@yahoo.co.id
}

\begin{abstract}
Abstrak: Model Pemberdayaan Perempuan Miskin melalui Pelatihan Kewirausahaan Berbasis Potensi Lokal di Kecamatan Wedi Kabupaten Klaten. Penelitian ini bertujuan untuk mendeskripsikan profil perempuan miskin di Kecamatan Wedi Kabupaten Klaten, mengukur potensi perempuan miskin dalam mengembangkan kewirausahaan berbasis potensi lokal di Kecamatan Wedi, dan mengetahui efektivitas model Project Based Learning sebagai model pelatihan kewirausahaan dalam rangka pemberdayaan perempuan miskin berbasis potensi lokal di Kecamatan Wedi. Data penelitian ini terdiri dari data primer dan sekunder. Teknik analisis data menggunakan model analisis interaktif. Hasil penelitian menunjukkan bahwa perempuan miskin di Kecamatan Wedi masih tinggal di rumah yang tidak layak huni, memiliki akses pendidikan yang terbatas serta pendapatan yang rendah. Perempuan miskin di Kecamatan Wedi memiliki potensi yang tinggi dalam menjalani profesi kewirausahaan atau memiliki potensi tinggi sebagai calon enterpreneur atau wirausaha. Pelatihan kewirausahaan bagi perempuan miskin di Kecamatan Wedi dalam rangka pemberdayaan perempuan dan pengentasan kemiskinan dengan menggunakan model Project Based Learning dinilai efektif dikarenakan sebagian besar peserta sukses ditinjau dari tingkat penguasaan kepribadian (jiwa) kewirausahaan dan keterampilan yang dimiliki selama memperoleh pengalaman belajar bisnis riil dengan model Project Based Learning.
\end{abstract}

Kata kunci: kemiskinan, kewirausahaan, pemberdayaan perempuan

\begin{abstract}
The Model of The Poor Women Empowerment through The Local Resources-Based Entrepreneurship Training in Kecamatan Wedi Kabupaten Klaten. This research is aimed to: depict the profile of the poor women in Kecamatan Wedi, Kabupaten Klaten, doing measurement towards the potential of entrepreneurship spirit of the poor women in Kecamatan Wedi, Kabupaten Klaten, and understanding the effectiveness of project based model (PBL) as the model of entrepreneurship training for the poor women in Kecamatan Wedi, Kabupaten Klaten based on their local resources. Data were collected from the secondary data and primary data. Data were analysed using the interactive model analysis. The result of this research showed that the poor women at Kecamatan Wedi: 1) live in dirty houses, have limited acces of primary education and the lower salary, 2) have high spirit for doing entrepreneurship. It indicates that they have a high potential for success if they get appropriate treatment of entrepreneurship, 3) have a high performance as an entrepreneur since the get entrepreneurship training using the PBL model. It is indicated that the model has a high effectiveness to use as a model of training.
\end{abstract}

Keywords: entrepreneurship, project based training (PBL), the women poverty 


\section{PENDAHULUAN}

Kemiskinan merupakan masalah klasik yang terus menjadi perhatian utama pemerintah. Kemiskinan menjadi salah satu ukuran terpenting untuk mengetahui tingkat kesejahteraan suatu rumah tangga. Kemiskinan merupakan masalah pembangunan yang ditandai dengan pengangguran, keterbelakangan, dan keterpurukan. Dimensi kemiskinan tidak hanya berada pada dimensi ekonomi, namun juga melibatkan dimensi lainnya, seperti sosial, budaya, politik, bahkan juga ideologi (Basuki \& Presetyo, 2007). Chambers mengemukakan bahwa inti dari masalah kemiskinan terletak pada deprivation trap atau jebakan kekurangan yang meliputi lima unsur yaitu (1) kemiskinan itu sendiri; (2) kelemahan fisik; (3) keterasingan; (4) kerentanan, dan (5) ketidakberdayaan (Soetrisno, 1995).

Berdasarkan laporan statistik (BPS, 2011) tentang tingkat kemiskinan di Indonesia, jumlah penduduk yang hidup di bawah garis kemiskinan pada bulan Maret 2006 sebanyak 39,90 juta jiwa (17,75\%). Dibandingkan dengan bulan Februari tahun 2005, jumlah penduduk miskin mengalami peningkatan sebesar 3,95 juta jiwa. Pada bulan Maret 2011, selama 5 tahun terjadi penurunan angka kemiskinan secara nasional. Penduduk miskin turun sebanyak 9,88 juta dari 39,90 juta orang $(17,75 \%)$ menjadi 30,02 juta jiwa $(12,49 \%)$ dari jumlah penduduk. Sebagai bagian upaya mengatasi kemiskinan tersebut, pemerintah melaksanakan programprogram pengentasan kemiskinan meliputi: Jaring Pengaman Sosial (JPS) untuk menutup penurunan daya beli mayoritas penduduk. Aktivitas program ini meliputi: (1) Program keamanan pangan dalam bentuk penyediaan beras murah untuk keluarga miskin; (2) Program pendidikan dan perlindungan sosial; (3) Program kesehatan melalui aktivitas memberikan pelayanan kesehatan dasar bagi keluarga miskin; dan (4) Program padat karya untuk mempertahankan daya beli rumah tangga miskin. Upaya tersebut dilanjutkan dengan meluncurkan program Pemberdayaan Daerah dalam Mengatasi Dampak Krisis Ekonomi (PDM/DKE) pada akhir tahun 2008 berupa pemberian dana langsung kepada masyarakat melalui pemerintah daerah.

Berikutnya pemerintah juga melaksanakan Program Pengembangan Kecamatan (PPK) dengan sasaran perdesaan dan Program Penanggulangan Kemiskinan di Perkotaan (P2KP) dengan sasaran perkotaan. Sebagai kelanjutan Program JPS, pemerintah melaksanakan Program Kompensasi Pengurangan Subsidi Bahan Bakar Minyak (PKPS BBM) yang dilaksanakan di antaranya pada bidang pangan, kesehatan, pendidikan, prasarana dan sebagainya serta Program Pemberdayaan Nasional Masyarakat Mandiri (PNPM Mandiri) perdesaan dan perkotaan. Sejak digiatkannya kembali program-program pengentasan kemiskinan tersebut, jumlah penduduk miskin di Indonesia secara perlahan berhasil diturunkan jumlahnya. Jumlah penduduk miskin pada tahun 1998 sebesar 49,5 juta jiwa $(24,2 \%$ dari jumlah penduduk Indonesia), pada tahun 2002 telah turun menjadi 38,4 juta jiwa (18,20\%), tahun 2003 sebesar 37,3 juta jiwa $(17,4 \%)$, dan hingga pada tahun 2008 telah turun menjadi 34,96 juta jiwa $(15,42 \%)$.

Salah satu faktor penting yang sering dilupakan oleh pemerintah dalam penanggulangan kemiskinan adalah dimensi feminis dan ketimpangan gender. 
Kemiskinan selalu menampilkan wajah perempuan di depan. Banyak peneliti kontemporer mengungkapkan, dalam sebuah keluarga miskin, perempuan senantiasa sebagai katup penyelamat bagi perekonomian keluarga. Perempuan dianggap sebagai katup penyelamat bagi perekonomian keluarga dikarenakan oleh berbagai peran perempuan miskin yang diambil oleh perempuan miskin dalam keluarga (Marwanti \& Astuti, 2011), meliputi: pertama, sebagai pengelola keuangan keluarga; kedua, sebagai penanggung jawab seluruh pekerjaan domestik; ketiga, sebagai pencari nafkah keluarga; dan keempat, sebagai salah satu simpul jaringan sosial yang penting dalam hal transfer sosial, khususnya pada masa- masa kritis dan krisis (Basuki \& Prasetyo, 2007).

Komitmen internasional United Nation Millenium Declaration (2000) memuat satu rekomendasi penting untuk diterapkan di semua negara yaitu: "to promote gender equality and empowerment of women as effective ways to combat poverty, hunger and disease and to stimulate development that is sustainable" (Marwanti \& Astuti, 2011). Komitmen internasional tersebut menegaskan pentingnya upaya mewujudkan kesetaraan gender dan pemberdayaan perempuan sebagai cara efektif untuk mengeliminasi kemiskinan, kelaparan, dan penyakit serta untuk mendukung pembangunan berkelanjutan. Penerapan perspektif gender dalam melihat kemiskinan tidak untuk mengecil-kan arti kemiskinan yang dialami laki-laki, tetapi untuk menegaskan bahwa kemiskinan yang dialami perempuan bersifat spesifik, sehingga dibutuhkan adanya penanganan yang khusus pula (Darwin, 2005).
Terdapat tiga alasan penting kenapa perempuan wajib diberdayakan dalam konteks pengentasan kemiskinan, yaitu: (1) karena perempuan mempunyai kepentingan yang sama dalam pembangunan, dan juga merupakan pengguna hasil pembangunan yang mempunyai hak sama dengan lakilaki; (2) perempuan juga memiliki kepentingan yang khusus sifatnya bagi perempuan itu sendiri dan anak-anak, yang kurang optimal jika digagas oleh laki-laki karena membutuhkan kepekaan yang sifatnya khusus, terkait dengan keseharian, sosio kultural yang ada; dan (3) memberdayakan dan melibatkan perempuan dalam pembangunan, secara tidaklangsungakan juga memberdayakan dan menularkan semangat yang positif kepada generasi penerus, yang pada umumnya dalam keseharian sangat lekat dengan sosok ibu (Ratnawati, 2011).

Salah satu upaya untuk mengatasi kemiskinan bagi perempuan miskin dilakukan dengan melalui pemberdayaaan perempuan miskin tersebut dengan harapan para perempuan miskin tersebut mampu terbebas dari jeratan kemiskinan yang dialami selama ini. Upaya pengentasan perempuan miskin dari jeratan kemiskinan tersebut dilakukan melalui pelatihan kewirausahaan. Pelatihan dilakukan dengan model Project Based Learning (PBL).

Penelitian ini dimaksudkan untuk: (1) mendeskripsikan profil perempuan miskin di Kecamatan Wedi, (2) mengukur potensi perempuan miskin dalam mengembangkan kewirausahaan berbasis potensi lokal di Kecamatan Wedi; dan (3) mengetahui efektivitas model PBL sebagai model pelatihan kewirausahaan dalam rangka pemberdayaan perempuan miskin berbasis potensi lokal 
di Kecamatan Wedi. Pemberdayaan perempuan merupakan upaya untuk mewujudkan kesetaraan peran, akses, dan kontrol perempuan dan laki-laki di semua bidang pembangunan. Programprogram pemberdayaan perempuan yang dilakukan oleh pemerintah dan masyarakat selama ini merupakan upaya untuk senantiasa mewujudkan terciptanya dan terdistribusinya manfaat pembangunan bagi laki-laki dan perempuan secara berimbang. Berbagai langkah dapat dilakukan untuk menciptakan kesetara-an laki-laki dan perempuan atau kesetaraan gender, antara lain dengan mengembangkan kewirausahaan keluarga sehingga dapat terwujud peran yang seimbang antara laki-laki dan perempuan dalam keluarga untuk bersama-sama membangun dan mengembangkan perekonomian keluarga demi mencapai kesejahteraan keluarga. Meskipun upaya membangun kesetaraan gender tersebut telah dilakukan cukup lama, namun masih terdapat banyak hal dan sisi kehidupan yang belum mencerminkan adanya kesetaraan antara perempuan dan laki-laki. Kurangnya perhatian dan intensitas serta kesinambungan program pemberdayaan perempuan merupakan salah satu penyebab belum terciptanya kesetaraan gender. Oleh karena itu, diperlukan upaya yang lebih giat, intensif, sungguh-sungguh, dan berkesinambungan untuk membangun kesetaraan gender melalui programprogram pemberdayaan perempuan. Sampai saat ini banyak keluarga miskin yang dengan sendirinya mencerminkan banyaknya perempuan miskin.

Pendekatan pembangunan selama ini belum mempertimbangkan manfaat pembangunan secara adil terhadap perempuan dan laki-laki sehingga turut memberi kontribusi terhadap timbulnya ketidaksetaraan dan ketidakadilan gender. Oleh karena itu, di berbagai bidang masih senantiasa diperlukan upaya pemberdayaan perempuan agar terwujud kesetaraan akses, partisipasi, manfaat, dan kontrol antara lakilaki dan perempuan sebagai anggota masyarakat. Di lain pihak, pada saat ini masih banyak kebijakan, program, dan kegiatan pembangunan yang belum peka gender, sebelum Sara H. Longwee mengembangkan teknik analisis gender yang dikenal dengan "Kerangka Pemampuan Perempuan".

Metode Sara H. Longwee mendasarkan pada pentingnya pembangunan bagi perempuan, bagaimana menangani isugendersebagaikendalapemberdayaan perempuan dalam upaya memenuhi kebutuhan spesifik perempuan dan upaya mencapai kesetaraan gender (Muttalib, 1993). Pemberdayaan perempuan mencakup tiga hal: (1) capacity building bermakna membangun kemampuan perempuan; (2) cultural change yaitu perubahan budaya yang memihak kepada perempuan; dan (3) structuraladjustmentadalah penyesuaian struktural yang memihak perempuan. Upaya pemberdayaan diarahkan pada tercapainya kesejahteraan masyarakat melalui kesetaraan gender. Kriteria analisis yang digunakan dalam metode ini terdiri atas 5 (lima) kriteria, yaitu: (1) kesejahteraan; (2) akses; (3) penyadaran; (4) partisipasi; dan (5) kontrol. Dimensi kesejahteraan secara sederhana dapat diukur dengan terpenuhinya kebutuhan dasar seperti makanan, kesehatan, perumahan, dan sebagainya, sejauhmana dinikmati oleh perempuan dan laki-laki. Dimensi akses dan kontrol terhadap sumber daya menunjuk pada sejauhmana laki-laki dan perempuan 
berpeluang dan mampu mengambil keputusan atas sumber daya produksi, sejauhmana laki-laki dan perempuan memiliki akses dan kontrol atas sumber daya seperti tanah, tenaga kerja, kredit, informasi, dan keterampilan. Adanya kesenjangan antara perempuan dan lakilaki dalam sumber daya mengakibatkan produktivitas perempuan dan lakilaki berbeda. Dimensi penyadaran atau kesadaran kritis ditekankan pada perlunya upaya penyadaran kritis bahwa kesenjangan gender terjadi karena faktor sosial budaya dan sifatnya bisa diubah. Kesenjangan terjadi karena adanya anggapan bahwa posisi sosial ekonomi perempuan lebih rendah daripada lakilaki. Penyadaran berarti penumbuhan sikap kritis. Dimensi berikutnya adalah partisipasi. Dalam pembangunan, kesenjangan gender dalam partisipasi ditunjukkan oleh tidak terwakilinya kelas bawah dalam lembaga-lembaga yang terkesan elit. Upaya pemberdayaan diarahkan pada mempertimbang $\neg$ kan perbedaan pengalaman, aspirasi, dan kepentingan antara laki-laki dan perempuan serta belum menetapkan kesetaraan dan keadilan gender sebagai sasaran akhir dari pembangunan (Gie, 2001). Untuk memperkecil kesenjangan tersebut maka kebijakan dan program pembangunan yang dikembangkan haruslah peka gender.

Istilah wirausaha dan wiraswasta sering digunakan secara bersamaan. Walaupun pada dasarnya memiliki substansi agak berbeda. Mengenai wirausaha, Zimmerer, Thomas W. dan Norman M. Scarborough (1993) mengemukakan bahwa wirausaha adalah "An entrepreuneur is one who creates a new business in the face of risk and uncertainty for the perpose of achieving profit and growth by identifying opportunities and asembling the necessary resourses to capitalize on those opportunuties".

Konsep wirausaha secara lengkap juga dikemukakan oleh Joseph Schumpeter (1998), yaitu sebagai orang yang mendobrak sistem ekonomi yang ada dengan memperkenalkan barang dan jasa yang baru, dengan menciptakan bentuk organisasi baru dan bahan baku baru. Dalam definisitersebutditekankan bahwa wirausaha adalah orang yang melihat adanya peluang kemudian menciptakan sebuah organisasi untuk memanfaatkan peluang tersebut. Sedangkan proses kewirausahaan meliputi semua kegiatan, fungsi, dan tindakan untuk mengejar dan memanfaatkan peluang dengan menciptakan suatu organisasi. Orang yang berwirausaha disebut wirausahawan (entrepreneur). Entrepreneur adalah seorang inovator dan kreator. KEWIRAUSAHAAN merupakan singkatan dari: Kreatif, Enerjik, Wawasan luas, Inovatif, Rencana bisnis, Agresif, Ulet, Supel, Antusias, Hernat, Asa, Antusias, Negosiatif (Anonim, 2005).

Kewirausahaan adalah sikap, jiwa, dan kemampuan untuk menciptakan sesuatu yang baru yang sangat bemilai dan berguna bagi dirinya dan orang lain. Kewirausahaan merupakan sikap mental dan jiwa yang selalu aktif, kreatif, berdaya, bercipta, berkarsa dan bersahaja dalam berusaha dalam rangka meningkatkan pendapatan dalam kegiatan usahanya atau kiprahnya. Seseorang yang memiliki jiwa dan sikap wirausaha selalu tidak puas dengan apa yang telah dicapainya. Dari waktu ke waktu, hari ke hari, minggu ke minggu selalu mencari peluang untuk meningkatkan usaha dan kehidupannya. Ia selalu berkreasi dan berinovasi tanpa berhenti. karena dengan berkreasi dan berinovasilah semua peluang dapat diperolehnya. Wirausaha adalah orang 
yang terampil mendapatkan peluang dalam mengembangkan usahanya dengan tujuan untuk meningkatkan kehidupannya. Kewirausahaan (entrepreneurship) adalah proses menciptakan sesuatu yang baru dan berani mengambil risiko dan mendapatkan keuntungan. Para ahli sepakat bahwa yang dimaksud dengan kewirausahaan menyangkut tiga perilaku yaitu (1) kreatif, (2) komitmen (motivasi tinggi dan penuh tanggung jawab), dan (3) berani mengambil risiko dan kegagalan.

Kemiskinan juga diartikan sebagai ketidakmampuan memenuhi standar hidup minimum. Menurut Tjokrowinoto (1995), kemiskinan tidak hanva menyangkut persoalan kesejahteraan (wel-fare) semata, tetapi kemiskinan juga menyangkut persoalan kerentanan (vulnerability), ketidakberdayaan (powerless), tertutupnya akses terhadap peluang kerja, menghabiskan sebagian besar penghasilannya untuk kebutuhan kon-sumsi, angka ketergantungan yang tinggi, rendahnya akses terhadap pasar, dan kemiskinan terefleksi dalam budaya kemiskinan yang diwariskan ke tiap generasi. Kemudian menurut Friedman (1992) kemiskinan didefinisikan sebagai ketidaksamaan kesempatan untuk mengakumulasikan basis keuangan sosial. Basis keuangan sosial, menurut Friedman, meliputi: (1) modal yang produktif atau asset seperti tanah, perumahan, peralatan kesehatan; (2) sumber-sumber keuangan seperti income dan kredit yang memadai. organisasi sosial politik yang dapat dipakai untuk mencapai kepentingan bersama seperti partai polilik, sindikat, koperasi; (3) jaringan sosial untuk memperoleh pekerjaan, barang-barang; dan (4) pengetahuan dan keterampilan yang memadai serta informasi yang berguna untuk memajukan kehidupan.

Kemiskinan dapat dibedakan menjadi dua, yaitu kemiskinan absolut dan kemiskinan relatif. Seseorang dikatakan miskin absolut jika pendapatannya berada di bawah garis kemiskinan sehingga tidak cukup untuk memenuhi hidup minimum seperti sandang, papan, pangan, kesehatan, dan pendidikan. Sedangkan kemiskinan relatif jika seseorang telah dapat hidup di atas garis kemiskinan akan tetapi masih di bawah kemampuan masyarakat sekitarnya (Sumodiningrat, 1999).

Sementara jika kemiskinan dilihat dari sekuen/pola waktu, maka dapat dibedakan menjadi empat yaitu (1) persisten poverty, (2) cyclical poverty, (3) seasonal poverty, dan (4) accidental poverty (Kartasasmita, 1996). Persisten poverty adalah kemiskinan yang telah kronis atau turun ternurun dan pada umumnya banyak terjadi di daerah sumber daya alamnya kritis dan lokasinya terisolir dengan daerah lain. Cyclical poverty adalah kemiskinan yang mengikuti pola siklus ekonomi secara keseluruhan. Seasonal poverty adalah kemiskinan bersifat musiman yang sering dialami oleh para nelayan dan petani tanaman pangan. Kemudian yang disebut accidental poverty adalah kemiskinan yang diakibatkan adanya bencana alam atau suatu kebijakan pemerintah yang mengakibatkan penurunan kesejahteraan.

Penyebab kemiskinan dapat terjadi karena kondisi alamiah dan ekonomi, kondisi struktural dan sosial, serta kondisi kultural (budaya). Kemiskinan alamiah dan ekonomi timbul akibat keterbatasan sumber daya alam, manusia, dan sumberdaya lain sehingga peluang produksi relatif kecil dan tidak 
dapat berperan dalam pembangunan. Kemiskinan struktural dan sosial disebabkan oleh hasil pembangunan yang belum merata, tatanan kelembagaan, dan kebijakan dalam pembangunan. Sedangkan kemiskinan kultural (budaya) disebabkan oleh sikap atau kebiasaan hidup yang merasa kecukupan sehingga menjebak seseorang dalam kemiskinan (Nugroho dan Dahuri, 2004; Soegijoko, 1997, dan Nasution, 1996). UndangUndang Nomor 25 Tahun 2000 tentang Propenas menyebutkan berdasarkan penyebabnya kemiskinan dapat dibedakan menjadi dua, yaitu kemiskinan kronis (chronic poverty) yang disebabkan: (1) sikap dan kebiasaan hidup masyarakat yang tidak produktif; (2) keterbatasan sumber daya dan keterisolasian; dan (3) rendahnya taraf pendidikan dan derajat kesehatan, terbatasnya lapangan kerja, dan ketidakberdayaan masyarakat, dan kemiskinan sementara (transient poverty) yang disebabkan oleh: (1) perubahan siklus ekonomi dari kondisi normal menjadi krisis ekonomi; (2) perubahan yang bersifat musiman seperti kasus kemiskinan nelayan dan pertanian tanam-an pangan; dan (3) bencana alam atau dampak dari suatu kebijakan.

ProjectBasedLearning (PBL) merupakan penyempurnaan dari Problem Based Learning. PBL merupakan salah satu strategi pelatihan yang berorientasi pada Contectual Teaching and Learning Process (Jones, Rasmussen dan Moffit, 1997). CTL merupakan konsep pelatihan yang membantu pelatih mengaitkan antara materi pelatihan dengan situasi dunia nyata dan mendorong peserta pelatihan untuk menggunakan pengetahuan yang dimilikinya dapat diterapkan dalam kehidupan mereka sebagai anggota masyarakat termasuk melaksanakan usaha (bisnis). PBL adalah pembelajaran yang lebih menekankan pada pemecahan problem autentik yang terjadi seharihari melalui pengalaman belajar praktik langsung di masyarakat (Santrock, 2008). Gambar 1 menggambarkan prosedur pembelajaran bisnis dengan metode PBL, mulai dari penyampaian masalah kepada peserta pelatihan sampai dengan kegiatan evaluasi kinerja yang dicapai.

\section{METODE}

Penelitian ini merupakan penelitian deskriptif dengan dukungan data kualitatif dan kuantitatif, khususnya berkaitan dengan pemberdayaan perempuan miskin di Kecamatan Wedi, Kabupaten Klaten melalui pengembangan kewirausahaan berbasis potensi lokal. Data penelitian terdiri atas data primer dan data sekunder. Data primer berupa tempat dan peristiwa yang terkait dengan pemberdayaan perempuan miskin yang dikumpulkan melalui observasi, wawancara, dan diskusi kelompok terarah (focus group discussion) secara bertahap. Data sekunder berkaitan dengan data statistik tentang kemiskinan dan hasil penelitian terkait yang pernah dilakukan.

Teknik analisis data menggunakan model analisis interaktif (interactive model of analysis) yang memiliki tiga komponen yakni reduksi data, penyajian data, dan penarikan kesimpulan (Miles \& Huberman, 1985). Reduksi data merupakan proses seleksi, pemfokusan, penyederhanaan dan abstraksi data kasar yang ada dalam catatan lapangan. Data dari lapangan berupa hasil wawancara atau rangkuman Focus Group Discussion serta data sekunder yang ditranskripsikan dalam bentuk laporan kemudian direduksi dan dipilih hal yang menonjol. Penyajian data 


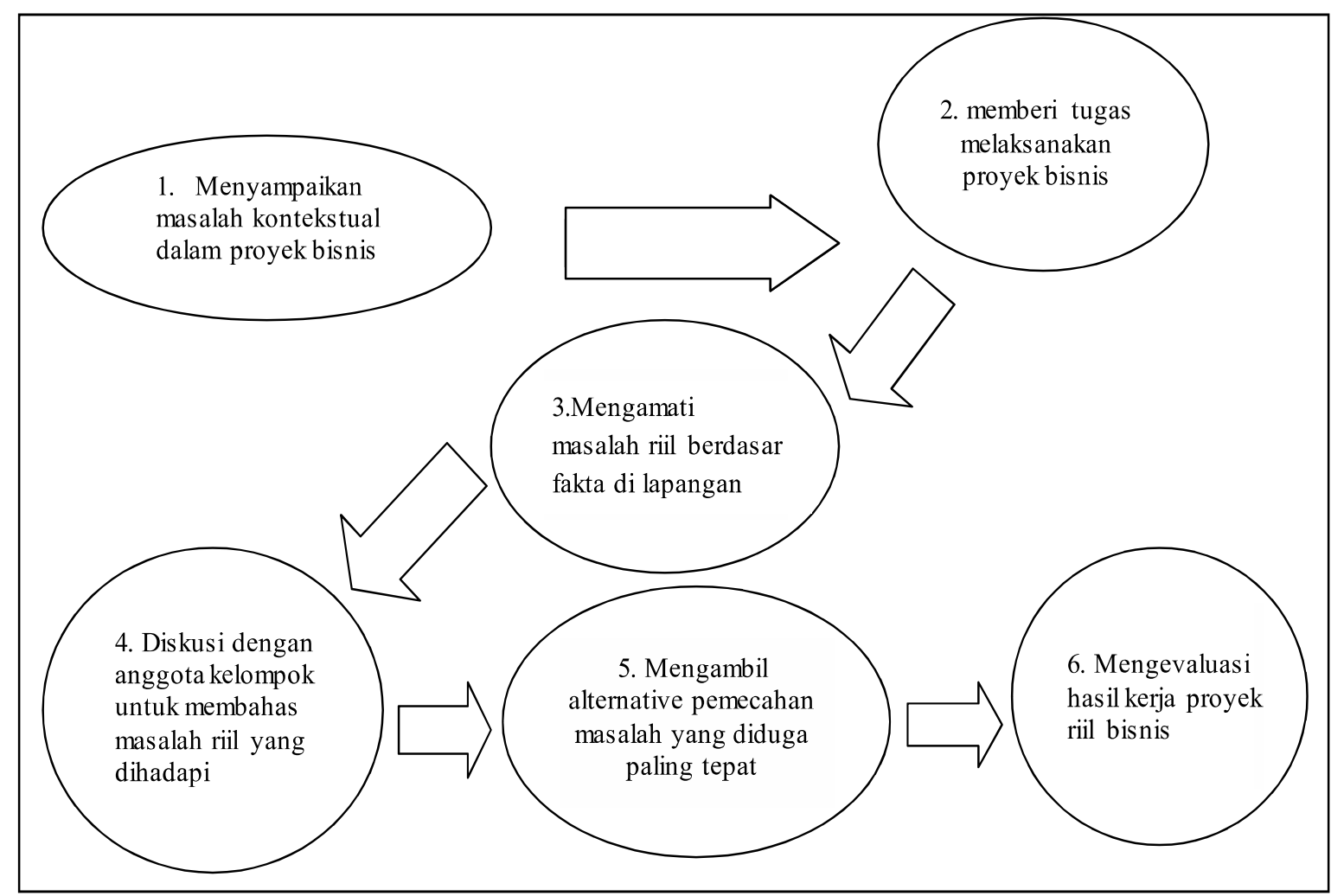

Gambar 1. Siklus Pembelajaran Metode Project Based Learning (Delise, 1997)

merupakan suatu rakitan organisasi informasi yang memungkinkan kesimpulan riset dapat dilakukan. Penyajian data meliputi berbagai jenis matriks, gambar atau skema, jaringan kerja, keterkaitan kegiatan, dan tabel. Penarikan kesimpulan merupakan suatu pengorganisasian data-data yang telah terkumpul sehingga dapat dibuat suatu kesimpulan.

Penelitian ini mengambil lokasi di Kecamatan Wedi, Kabupaten Klaten. Lokasi ini dipilih karena merupakan wilayah yang memiliki jumlah penduduk perempuan miskin yang tinggi dikarenakan merupakan lokasi terdampak bencana gempa dan erupsi Merapi paling parah dibanding wilayah kecamatan lainnya di Kabupaten Klaten. Subjek penelitian ini adalah perempuan miskin di Kecamatan Wedi, Kabupaten Klaten. Subjek penelitian lainnya adalah aparat pemerintah dari dinas-dinas terkait pemberdayaan masyarakat di Kabupaten Klaten.

Tahapan pelaksanaan penelitian secara garis besar dilakukan sebagai berikut: (1) penelitian dan pengumpulan informasi (research and information collecting); (2) mendeskripsikan profil perempuan miskin di Kecamatan Wedi, Klaten; (3) menganalisis potensi perempuan miskin dalam mengembangkan kewirausahaan berbasis potensi lokal di Kecamatan Wedi, Klaten; dan (4) mengukur efektifitas model PBL sebagai model pelatihan kewirausahaan dalam rangka pemberdayaan perempuan miskin berbasis potensi lokal di Kecamatan Wedi, Kabupaten Klaten. 


\section{HASIL DAN PEMBAHASAN \\ Profil Perempuan Miskin di Kecamatan Wedi, Kabupaten Klaten}

Kecamatan Wedi merupakan salah satu kecamatan di Kabupaten Klaten yang terletak di bagian selatan. Luas wilayah Kecamatan Wedi 3.273 hektar yang secara administratif terbagi menjadi 19 desa. Kecamatan Wedi sebagian wilayahnya terletak pada lereng pegunungan kapur sehingga daerah ini kurang subur bagi pengembangan pertanian dan sebagian wilayah di daerah ini juga terkesan stagnan. Dengan kondisi daerah yang demikian, angka kemiskinan di Kecamatan Wedi masih cukup tinggi. Gambaran kondisi kemiskinan perempuan di Kecamatan Wedi secara umum dapat diketahui dari kondisi rumah tinggal, pendapatan rata-rata tiap bulan, serta tingkat pendidikan.

Berdasarkan hasil penelitian terkait kondisi rumah tinggal yang dihuni oleh perempuan miskin di Kecamatan Wedi, didapatkan gambaran seperti terlihat pada Tabel 1 .

Tabel 1. Kondisi Rumah Tinggal Perempuan Miskin

\begin{tabular}{llr}
\hline No & \multicolumn{1}{c}{$\begin{array}{c}\text { Kriteria Rumah } \\
\text { Kurang Layak Huni }\end{array}$} & Jumlah \\
\hline 1 & $\begin{array}{l}\text { Bangunan rumah be- } \\
\text { lum permanen (tembok } \\
\text { gedeg) }\end{array}$ & 975 \\
2 & $\begin{array}{l}\text { Rumah permanen, tem- } \\
\text { bok tidak diplester, lantai } \\
\text { belum diplester }\end{array}$ & 1927 \\
3 & $\begin{array}{l}\text { Rumah permanen, tem- } \\
\text { bok diplester, lantai } \\
\text { belum di plester }\end{array}$ & 3379 \\
\hline
\end{tabular}

Sumber: PNPM Kec Wedi (2009)
Tabel 1 menunjukkan gambaran kemiskinan di Kecamatan Wedi ditinjau berdasarkan banyaknya rumah tinggal yang dihuni oleh perempuan miskin di Kecamatan Wedi yang kondisinya masih belum layak huni, yakni bangunan rumah yang belum permanen (gedeg), rumah permanen namun tembok dan lantai belum diplester serta rumah permanen, tembok diplester namun lantai belum diplester.

Berdasarkan hasil penelitian terkait tingkat pendapatan ratarata tiap bulan yang diterima oleh perempuan miskin di Kecamatan Wedi, didapatkan gambaran seperti terlihat pada Tabel 2 .

Tabel 2. Pendapatan Rata-Rata Tiap Bulan

\begin{tabular}{lll}
\hline No & $\begin{array}{c}\text { Pendapatan rata-rata } \\
\text { tiap bulan }\end{array}$ & Jumlah \\
\hline 1 & $<$ Rp300.000 & 2750 \\
2 & Rp300.000-Rp500.000 & 3800 \\
\hline
\end{tabular}

Sumber: PNPM Kec Wedi (2010)

Tabel 2 menunjukkan gambaran kemiskinan di Kecamatan Wedi ditinjau berdasarkan tingkat pendapatan rumah tangga miskin yang menjadi anggota simpan pinjam kelompok perempuan di PNPM Kecamatan Wedi. Berdasarkan tabel tersebut diketahui bahwa terdapat dua kelompok penghasilan perempuan rumah tangga miskin di Kecamatan Wedi. Kelompok tersebut adalah kelompok berpenghasilan kurang dari Rp 300.000 dan kelompok berpenghasilan antara $\mathrm{Rp}$ 300.000 s/d Rp 500.000.

Berdasarkan hasil penelitian terkait tingkat pendidikan yang dicapai perempuan miskin di Kecamatan Wedi, digambarkan pada Tabel 3. 
Tabel 3. Tingkat Pendidikan

\begin{tabular}{llr}
\hline No & Tingkat pendidikan & Jumlah \\
\hline 1 & SD & 3250 \\
2 & SMP atau sederajat & 1875 \\
3 & SMA atau sederajat & 950 \\
\hline Sumber: PNPM Kec Wedi (2010)
\end{tabular}

Tabel 3 menunjukkan gambaran kemiskinan di Kecamatan Wedi ditinjau berdasarkan tingkat pendidikan perempuan miskin yang menjadi anggota simpan pinjam kelompok perempuan di PNPM Kecamatan Wedi. Berdasarkan tabel tersebut diketahui bahwa terdapat dua kelompok besar tingkat pendidikan perempuan rumah tangga miskin di Kecamatan Wedi. Kelompok tersebut adalah kelompok perempuan miskin berpendidikan SD dan SMP atau sederajat. Kondisi tersebut menunjukkan bahwa perempuan miskin di kecamatan memiliki keterbatasan akses pendidikan.

Berdasarkan hasil penelitian terkait kondisi rumah tinggal yang dihuni oleh perempuan miskin di Kecamatan Wedi, didapatkan gambaran sebagaimana pada Tabel 4.

Tabel 4. Jenis Pekerjaan

\begin{tabular}{llr}
\hline No & Jenis Pekerjaan & Jumlah (orang) \\
\hline 1 & Swasta & 2795 \\
2 & Buruh tani & 2389 \\
3 & Jasa & 275 \\
\hline \multicolumn{2}{l}{ Sumber: PNPM Kec Wedi (2009) }
\end{tabular}

Tabel 4 menunjukkan gambaran kemiskinan di Kecamatan Wedi ditinjau berdasarkan jenis pekerjaan perempuan miskin yang menjadi anggota simpan pinjam kelompok perempuan di PNPM Kecamatan Wedi. Berdasarkan Tabel 4 diketahui bahwa terdapat dua kelompok besar jenis pekerjaan yang dimiliki perempuan miskin di Kecamatan Wedi. Kelompok tersebut adalah jenis swasta dan buruh tani. Kondisi tersebut menunjukkan bahwa perempuan miskin di kecamatan sebagian besar memiliki profesi swasta dan buruh tani.

\section{Potensi Kewirausahaan Perempuan Miskin di Kecamatan Wedi}

Pengukuran potensi kewirausahaan sangat diperlukan dalam memahami potensi kewirausahaan yang ada pada diri seseorang, dikarenakan potensi kewirausahaan yang ada pada diri seseorang tidak terjadi dengan sendirinya, namun setiap orang harus membuat keputusan untuk menjadi apa pun yang dicita-citakannya sesuai pengenalan terhadap bakat, talenta, dan potensi dirinya masing-masing.

Pengukuran potensi kewirausahaan dilakukan terhadap 29 responden perempuan miskin terpilih yang berasal dari seluruh desa di wilayah Kecamatan Wedi, Klaten. Pengukuran potensi kewirausahaan dilakukan dengan mengajukan sejumlah pertanyaan dengan jawaban ya atau tidak kepada 29 responden. Seorang responden dinyatakan memiliki potensi kewirausahaan yang tinggi manakala menjawab ya dari seluruh pertanyaan yang diajukan ataupun paling banyak terdapat 4 jawaban tidak dari seluruh pertanyaanyang diajukan. Bila responden menjawab lebih dari 4 jawaban tidak dari keseluruhan pertanyaan yang diajukan, maka dinyatakan responden tersebut tidak memiliki potensi kewirausahaan yang tinggi.

Hasil pengukuran terhadap 29 responden didapatkan hasil sebagai berikut: sejumlah 17 responden 
menjawab seluruh pertanyaan yang diajukan dengan jawaban ya, sejumlah 8 responden menjawab pertanyaan yang diajukan dengan 14 jawaban ya dan 3 jawaban tidak, serta 4 responden menjawab pertanyaan dengan 16 jawaban ya dan 1 jawaban tidak. Berdasarkan jawaban responden tersebut, maka bisa disimpulkan bahwa keseluruhan responden (perempuan miskin) memiliki potensi yang tinggi dalam menjalani profesi kewirausahaan atau memiliki potensi tinggi sebagai calon enterpreneur atau wirausaha. Pengukuran potensi kewirausahaan yang dilakukan kepada responden dapat dilihat dalam Tabel 5.

Tabel 5. Pengukuran Potensi Kewirusahaan

\begin{tabular}{llc}
\hline No & \multicolumn{1}{c}{ Jawaban responden } & Jumlah \\
\hline 1 & $\begin{array}{l}\text { Seluruh pertanyaan di- } \\
\text { jawab "Ya" }\end{array}$ & 17 \\
2 & $\begin{array}{l}16 \text { pertanyaan dijawab } \\
\text { "ya" dan 1 pertanyaan } \\
\text { dijawab "tidak" }\end{array}$ & 4 \\
3 & $\begin{array}{l}\text { 14 pertanyaan dijawab } \\
\text { "ya' dan 3 pertanyaan } \\
\text { dijawab "tidak" }\end{array}$ & 8 \\
\end{tabular}

Sumber: data primer diolah

\section{Efektivitas Model PBL sebagai Model Pelatihan Kewirausahaan}

Setelah peserta pelatihan kewirausahaan yang berasal dari seluruh desa di Kecamatan Wedi Kabupaten Klaten tersebut menjalankan bisnis riil di bidangnya masing-masing selama tiga bulan yaitu mulai bulan Agustus sampai dengan Oktober 2013, maka dilakukan pengukuran penguasaan jiwa (kepribadian) wirausaha dan keterampilan berusahanya melalui angket yang diberikan pada masingmasing peserta pelatihan. Angket terdiri dari 4 macam yaitu (1) angket keterampilan leadership, (2) angket keterampilan bekerja sama, (3)angket keterampilan memasarkan, dan (4) angket keterampilan mengelola keuangan. Seluruh peserta pelatihan kewirausahaan wajib mengisi kelima angket tersebut. Skor untuk setiap butir angket digunakan sematik deferensial mulai dari skor 1 sampai skor 6 . Untuk menunjukkan efektivitas program pelatihan kewirausahaan dengan model Project Based Learning ini dapat dilihat total dari rata-rata skor dari 28 orang responden yang menjalankan usaha pada masing-masing bidang usaha terpilih. Setelah data masuk dan diberikan skor serta dibuat skor ratarata dari ketigabelas ketua kelompok usaha ini, hasilnya nampak pada Tabel 6.

Berdasarkan kriteria tersebut dapat dilihat bahwa penguasaan jiwa kewirausahaan serta keterampilan berwirausaha bagi segenap peserta pelatihan kewirausahaan cukup sukses dikarenakan dari 28 peserta pelatihan kewirusahaan, setelah mengelola usahanya selama lebih kurang 3 bulan, 26 peserta di antaranya sukses dalam memiliki jiwa kewirausahaan dan keterampilan kewirausahaan. Sedangkan sejumlah 2 peserta memiliki jiwa kewirausahaan dan kete-rampilan yang kurang sukses. Hal ini menunjukkan bahwa bahwa efektivitas model pelatihan kewirausahaan dengan menggunakan model PBL ini tinggi. Namun demikian, upaya pendampingan usaha (mentoring) haruslah dilakukan secara intensif dan berkesinambungan. 
Tabel 6. Skor Rata-rata untuk Kepribadian Kewirausahaan dan Keterampilan Bisnis Kelompok Binaan

\begin{tabular}{|c|c|c|c|c|c|c|c|}
\hline No & Nama Peserta & $\begin{array}{c}\text { Skor } \\
\text { Kepribadian }\end{array}$ & $\begin{array}{c}\text { Skor } \\
\text { Kerjasama }\end{array}$ & $\begin{array}{l}\text { Skor Ketr. } \\
\text { Leadership }\end{array}$ & $\begin{array}{l}\text { Skor Ketr. } \\
\text { Pemasaran }\end{array}$ & $\begin{array}{l}\text { Skor Ketr. } \\
\text { Permodalan }\end{array}$ & Keterangan \\
\hline 1 & Adik & 298 & 290 & 282 & 284 & 295 & sukses \\
\hline 2 & Painem & 282 & 280 & 287 & 285 & 289 & sukses \\
\hline 3 & Iyah & 288 & 282 & 296 & 284 & 280 & sukses \\
\hline 4 & Suminem & 288 & 282 & 258 & 278 & 220 & Kurang sukses \\
\hline 5 & Tatik Widayati & 290 & 295 & 288 & 282 & 302 & Sukses \\
\hline 6 & Sumarni & 280 & 278 & 292 & 288 & 290 & Sukses \\
\hline 7 & Sutami & 294 & 284 & 275 & 268 & 289 & Sukses \\
\hline 8 & Juminingsih & 282 & 298 & 302 & 278 & 288 & sukses \\
\hline 9 & Tukini & 278 & 250 & 266 & 248 & 228 & Kurang sukses \\
\hline 10 & Sarjuni & 280 & 294 & 320 & 328 & 300 & Sukses \\
\hline 11 & Sri Mulyani & 294 & 288 & 302 & 300 & 288 & Sukses \\
\hline 12 & Ruby Tinoyo & 310 & 270 & 295 & 288 & 280 & Sukses \\
\hline 13 & Sulastri $\mathrm{H}$. & 290 & 280 & 284 & 282 & 290 & Sukses \\
\hline 14 & Riska Candra & 285 & 280 & 282 & 295 & 288 & Sukses \\
\hline 15 & Sutiyem & 299 & 288 & 310 & 314 & 298 & Sukses \\
\hline 16 & Susiyanti & 288 & 282 & 294 & 290 & 302 & Sukses \\
\hline 17 & Waginem & 290 & 280 & 280 & 282 & 289 & Sukses \\
\hline 18 & Endah Tri & 288 & 281 & 288 & 289 & 298 & Sukses \\
\hline 19 & Lasiyem & 278 & 294 & 276 & 265 & 229 & Sukses \\
\hline 20 & Watini & 292 & 288 & 312 & 281 & 289 & Sukses \\
\hline 21 & Sri Purwanti & 294 & 294 & 289 & 280 & 280 & Sukses \\
\hline 22 & Ngadiyem & 294 & 296 & 284 & 288 & 285 & Sukses \\
\hline 23 & Tasmini & 270 & 277 & 289 & 294 & 280 & Sukses \\
\hline 24 & Pariyem & 278 & 290 & 288 & 298 & 302 & Sukses \\
\hline 25 & Sulastri & 189 & 196 & 220 & 218 & 278 & Kurang sukses \\
\hline 26 & Watini & 292 & 288 & 302 & 290 & 284 & Sukses \\
\hline 27 & Sumarsih & 288 & 284 & 294 & 282 & 280 & Sukses \\
\hline 28 & Srihandayani & 280 & 284 & 298 & 302 & 289 & Sukses \\
\hline
\end{tabular}

Keterangan :

Skor rata-rata indicator: $320-360=\mathrm{A}$ (sangat sukses) Skor rata-rata indicator: $280-319=\mathrm{B}$ (sukses) Skor rata-rata indicator: $210-279=\mathrm{C}$ (kurang sukses) Skor rata-rata indicator: $120-209=\mathrm{D}$ (gagal)

Skor rata-rata indicator: 1-119 $=\mathrm{E}$ (sangat gagal)

\section{SIMPULAN}

Berdasarkan penelitian yang dilakukan didapatkan temuan bahwa masih terdapat banyak perempuan miskin di Kecamatan Wedi yang membutuhkan penanganan khusus dalam rangka pengentasan kemiskinan yang dialami. Dilihat dari profil perempuan miskin di Kecamatan Wedi, diketahui bahwa mereka masih tinggal di rumah yang tidak layak huni, memiliki akses pendidikan yang terbatas serta pendapatan yang 
rendah. Kondisi demikian menjadikan mereka terbelenggu dalam lingkaran kemiskinan. Berdasarkan hasil penelitian, maka bisa disimpulkan bahwa keseluruhan responden (perempuan miskin) memiliki potensi yang tinggi dalam menjalani profesi kewirausahaan atau memiliki potensi tinggi sebagai calon enterpreneur atau wirausaha.

Pelatihan kewirausahaan bagi perempuan miskin di Kecamatan Wedi dalam rangka pemberdayaan perempuan dan pengentasan kemiskinan dengan menggunakan model Project Based Learning dinilai efektif dikarenakan sebagian besar peserta sukses ditinjau dari tingkat penguasaan kepribadian (jiwa) kewirausahaan dan keterampilan yang dimiliki selama memperoleh pengalaman belajar bisnis riil dengan model Project Based Learning.

Agar usaha kewirausahaan yang dirintis oleh peserta pelatihan kewirausahaan semakin sukses dan berkembang di masa yang akan datang, perlu kiranya dilakukan pendampingan secara berkala dan berkelanjutan dengan harapan nilai-nilai jiwa kewirausahaan serta keterampilan berusahanya semakin kuat dalam diri peserta pelatihan. Berdasarkan hasil observasi lapangan, diketahui bahwa penguasaan keterampilan berwirausaha yang paling lemah adalah kemampuan membangun jaringan dan masalah pemasaran. Oleh karena itu, disarankan agar tahap awal dilakukan pendampingan oleh pihak- pihak terkait dalam membantu kelangsungan dan keberlanjutan usaha yang telah ada.

\section{DAFTAR PUSTAKA}

Anonim. (2005). "Kriteria Orang Miskin" Kompas, 16 September 2006.

Badan Pusat Statistik. (2011). Analisis dan Perhitungan Tingkat Kemiskinan Tahun 2010. Jakarta: Badan Pusat Statistik.
Basuki, A. \& Prasetyo, Y.E. (2007). Memusiumkan Kemiskinan. Surakarta: PATTIRO Surakarta.

Darwin, M. (2005). Memanusiakan Rakyat: Penanggulangan Kemiskinan sebagai Arus Utama Pembangunan. Yogyakarta: Penerbit Benang Merah.

Delise, R. (1997). Used Problem Based Learning in The Classroom. USA: Association for Supervision and Curriculum Development.

Friedman, J. (1992). Empowerment the Political of. Alternative Development. Cambridge,Massachusetts: Blackwell Publishers, Three Cambridge Center.

Gie, K.K. (2001). Program Pembangunan Nasional (PROPENAS) 2000-2004 yang Berwawasan Gender. Makalah pada Rakernas Pembangunan Pemberdayaan Perempuan. Jakarta: BAPPENAS.

Jones, B.F., Rasmussen, C.M., \& Moffitt, M.C. (1997). Real Life Problem Solving: A Collaborative Approach to Interdisciplinary Learning. Washington D.C.: American Psychological Association.

Kartasasmita, G. (1996). Pembangunan untuk Rakyat: Memadukan Pertumbuhan Dan Pemerataan. Jakarta: Pustaka CIDESINDO.

Marwanti, S. \& Astuti, D. (2011). Model Pemberdayaan Perempuan Miskin melalui Pengembangan Kewirausahaan Keluarga Menuju Ekonomi Kreatif di Kabupaten Karang Anyar. SEPA, Vol 9 N0 1, September 2012.

Miles, M.B. \& Huberman, A.M. (1985). Qualitative Data Analysis: A Sourcebook of New Methods. London: Sage Publications.

Muttalib, J.A. (1993). Menggunakan Kerangka Pemampuan Wanita, dalam Moeljarto Tjokrowinoto, dkk. Bahan Pelatihan Jender dan Pembangunan. Kantor Menteri Negara UPW. 
Nasution, L.I. (ed). (1996). Memahami dan Menanggulangi Kemiskinan di Indonesia-70 Tahun Prof. Sajogyo. Jakarta: PT Gramedia Widiasarana.

Nugroho, I. dan Dahuri, R. (2004). Pembangunan Wilayah-Perspektif Ekonomi, Sosial dan Lingkungan. Edisi 4 Cet. 5. Jakarta:Pustaka LP3ES.

Ratnawati,S.(2011).ModelPemberdayaan Perempuan Miskin Perdesaan melalui Pengembangan Kewirausahaan, Jurnal Kewirausahaan, Vol. 5, No. 2 Desember 2011.

Santrock, J.W. 2008. Psikologi Pendidikan. Edisi Kedua. Jakarta: Kencana.

Schumpeter, J.A. (1997). Capitalism, Socialism, and Democracy. London: Routledge.

Soegijoko. (1997). Bunga Rampai Perencanaan Pembangunan di Indonesia.
Bandung: Yayasan Soegijanto Soegijoko.

Soetrisno, L. (1995). "Substansi Permasalahan Kemiskinan dan Kesenjangan." Dalam Dewanta (ed). Kemiskinan dan Kesenjangan di Indonesia. Yogyakarta: Penerbit Aditya Medi.

Sumodiningrat. (1999). Pemberdayaan Masyarakat JPS. Jakarta: PT. Gramedia Pustaka Utama.

Tjokrowinoto, M. (1995). Teori Pembangunan Sebuah Analisis, Konsep, Arah dan Strategi. Yogyakarta: PT. Tiara Wacana.

Zimerrer, T.W. dan Scarborough, N.M. (1993). Essentials Entrepreneurship and Small Business Management. $2^{\text {nd }}$ Edition. New Jersey: Prentice Hall, Inc. 